\title{
Arsitektur hijau mendukung adaptasi perilaku di masa pandemi Coronavirus disease (COVID-19) di Alun-Alun Kota Batam
}

\author{
Melinda Leony ${ }^{1^{*}}$, Suzanna Ratih Sari ${ }^{2}$ \\ ${ }^{1}$ Magister Arsitektur, Fakultas Teknik, Universitas Diponegoro \\ ${ }^{2}$ Fakultas Teknik, Universitas Diponegoro \\ *Koresponden E-mail: meldy95@gmail.com
}

(Diterima: 10 Juni 2021|Disetujui: 06 Januari 2022|Diterbitkan: 31 Januari 2022)

\begin{abstract}
This study aims to determine the principles of a green architecture approach that can support behavior change during the Covid-19 pandemic and to determine the arrangement of green architecture that can support behavior change during the Covid-19 pandemic in Batam City Square. This research method is to use literature study. The results show that in the Covid-19 pandemic maintaining environmental health is very crucial for our physical \& mental health, and the concept of green buildings is a way to create environmentally or ecologically friendly buildings. To achieve a balance between systems, interactions between humans and the environment. Spatial planning and design using the green building method in Batam City Square is expected to be able to overcome and minimize adverse impacts on human health and the environment, as well as overcome Covid-19 promotion efforts. With a development concept based on keeping your distance and washing your hands, an artistic and useful appearance for prevention can be maximized by architectural concepts through careful analysis and concepts in every planning and design.
\end{abstract}

Keywords: spatial planning; green open space; enviromental health

\section{PENDAHULUAN}

Coronavirus Disease (Covid-19) merupakan satu penyakit yang ditimbulkan oleh virus yang bernama corona yang mempengaruhi sistem pernapasan. Penyakit ini mulanya melanda Wuhan China (Heldavidson, 2020a). SARS-Cov-2 bukanlah virus baru (Heldavidson, 2020b). Menurut penjelasannya virus ini dapat bermutasi sendiri, singkatnya virus tetap merupakan jenis sama dan hanya akan berubah secara konsisten. Dinamakan SARS-Cov-2 karena virus corona mempunyai hubungan dengan virus penyebab MERS dan SARS (NIH, 2020).

Pandemi ini telah membawa kesedihan bagi seluruh negara termasuk Indonesia. Pandemi Covid-19 sudah berlangsung selama setahun menimbulkan kecemasan yang ada di kalangan masyarakat (Rachael D'amore, 2020). Akibat pandemi Covid-19, perilaku masyarakat harus berubah. Perubahan perilaku masyarakat secara tidak langsung mengubah desain bangunan yang juga ikut menyesuaikan. Beberapa waktu yang lalu terdapat istilah baru yaitu New normal life (Nicola et al., 2020). New normal life merupakan tatanan kehidupan dan kebiasaan baru di era pandemi saat ini. Kehidupan sosial baru akibat virus Covid-19 dalam hal ini merupakan beberapa peraturan mengenai protokol kesehatan yang diantaranya adalah memakai masker jika ke luar rumah, menjaga jarak, mencuci tangan dengan sabun sebelum menyentuh muka dan lain-lain. Tiga langkah pencegahan inilah yang menjadikan kehidupan sosial menjadi baru.
Kondisi pandemi Covid-19 membuat orang untuk tetap aktif di rumah pada waktu yang lama (Vasishta et al., 2020). Situasi ini menginspirasi para arsitek dan perencana lingkungan untuk membuat karya berdasarkan tata letak bangunan dan ruang terbuka untuk mendukung adaptasi terhadap perubahan perilaku selama pandemi Covid-19. Kontribusi ahli lansekap dalam menghadapi tatanan kehidupan baru bersama Covid-19 dibahas dalam seminar online tentang bangunan hijau (Hidayat et al., 2020).

Konsep green building merupakan salah satu cara untuk menciptakan bangunan yang ramah lingkungan atau ekologis untuk mencapai keseimbangan hubungan antara lingkungan dan manusia (Ding et al., 2018). Tema ini juga dapat menyelesaikan masalah lingkungan, yaitu pemanasan global. Oleh karena itu, mengambil tema green building ini sebagai contoh akan membawa banyak manfaat antara lain bangunan lebih tahan lama, bangunan lebih hemat energi, sedikit perbaikan gedung, hunian nyaman, dan penghuni akan menjadi lebih sehat (Cole, 2019).

Dalam tata letak bangunan hijau, metode perencanaan bangunan diciptakan untuk meminimalkan berbagai dampak buruk terhadap kesehatan manusia dan lingkungan. Sebagai pemahaman dasar tentang bangunan hijau yang berkelanjutan, elemen yang dimasukkan adalah lansekap dan dekorasi interior yang terintegrasi dalam hal arsitektur. Tujuan utama terciptanya bangunan hijau yaitu menciptakan desain ekologi, bangunan ramah lingkungan, bangunan alami dan pembangunan yang suistainable. Bangunan hijau 
dapat meningkatkan efisiensi dari energi, penghematan air, serta menggunakan bahan yang tidak merusak lingkungan. Desain bangunan hijau meliputi tata letak, konstruksi, pengoperasian serta perawatan bangunan (Olubunmi et al., 2016).

Menurut Ketua Umum Ikatan Arsitek Lansekap Indonesia (IALI) ini, arsitek lansekap pada dasarnya telah berperan dan berkontribusi dalam menciptakan lingkungan yang sehat, yang diperlukan bagi masyarakat dan lingkungan di era pandemi (Oebaidillah, 2020). Selain itu, peran lanskap juga sangat penting, selain keindahan taman atau ruang publik juga menjadikan ruang terbuka hijau memiliki pengaruh yang sehat dan menambah aktivitas baru. Dalam desain bangunan hijau, dirancang ruang terbuka dengan pepohonan dan tumbuhan hijau, yang tentunya menghadirkan suasana sejuk dan berbeda di lingkungan perkotaan, terutama pada masa pandemi (Hidayat et al., 2020).

Berdasarkan ruang lingkupnya sudah tentu dalam masa pandemi Covid-19 seperti ini terdapat pembatasan jumlah perkumpulan masyarakat, dengan adanya larangan pembatasan berkumpulnya masyarakat tersebut berdasarkan adanya tatanan kehidupan sosial yang baru, dalam perencanaan dan perancangan arsitektur perlu memasukkan unsur, yang mengadopsi anjuran Pemerintah yaitu jaga jarak, cuci tangan dengan sabun dan menggunakan masker: menjaga jarak, dan membasuh tangan adalah unsur yang berhubungan dengan disain, sementara pakai masker adalah unsur umum. Dari dua unsur: (1) Jaga jarak dan (2) cuci tangan akan menghasilkan desain yang lebih spesifik sebuah rancangan arsitektur.

Perencanaan dan perancangan ruang dengan metode green building diharapkan dapat mengatasi dan meminimalkan dampak yang tidak baik bagi kesehatan manusia dan lingkungan, serta mengatasi upaya penyebaran Covid-19 yang disebabkan oleh desain arsitektur yang tidak tepat (C. Otegbulu, 2011).

Green building adalah salah satu jenis bangunan yang ramah lingkungan, fondasinya adalah fokus pada perlindungan lingkungan global, dan fokus pada efisiensi energi, model keberlanjutan dan holistik (Priatman, 2002). Konsep green building di negaranegara maju dapat dikembangkan agar mengurangi polusi khususnya polusi udara dikota kota besar (Zhao et al., 2019). Green building merupakan subjek desain arsitektur atau pekerjaan perlindungan lingkungan yang menitikberatkan pada konservasi terhadap alam, berkelanjutan dan mengedepankan perlindungan terhadap lingkungan, serta mengunakan material yang tidak berlebih dan meminimalisir energi secara lokal maupun global (Anisa, 2014).

Tujuan utama dari bangunan hijau adalah membuat suatu desain yang ekologis, ramah terhadap lingkungan, alami serta berkelanjutan. Bangunan hijau dapat digunakan untuk meminimalisir pengunaan energi, menghemat lebih banyak air, serta menggunakan bahan yang sehat atau ramah terhadap manusia (Pradono, 2008). Desain bangunan hijau meliputi tata letak, konstruksi, pengoperasian dan pemeliharaan bangunan (Shen \& Faure, 2020).

Vale (2017) mengungkapkan bahwa prinsip bangunan hijau dalam "Mencapai Masa Depan yang Berkelanjutan dalam Desain Bangunan Hijau" ada beberapa macam diantaranya Hemat energy yang mana di dalam bangunan hijau, penggunaan energi secara rasional bisa disebut sebagai hal yang utama. Bangunan harus melihat pengunaan energinya sebelum atau sesudah terbangun. Desain arsitektur harus mampu menyesuaikan dengan lingkungannya, dan tidak mengubah kondisi lingkungan yang ada. Selanjutnya bekerja dengan iklim (menggunakan kondisi dan energi alam) metode green building sebuah bangunan menyesuaikan dengan lingkungannya, yang disesuaikan dengan bentuk dan pengoperasian bangunan tersebut yaitu memanfaatkan alam, iklim serta kondisi dilingkungannya.

Selain itu menghormati tapak adalah Perencanaan berdasarkan tapa dan bangunannya Tujuannya adalah memastikan bahwa struktur, bentuk dan pengoperasian bangunan sama sekali tidak merusak alam sekitarnya. Selanjutnya hormati pengguna (perhatikan membangun pengguna) Ada ikatan yang sangat erat antara pengguna dan arsitektur hijau. Permintaan bangunan hijau harus bisa mengetahu kondisi dari pengguna, yang pada saat itu ditetapkan dalam operasi dan perencanaannya.

Prinsip bangunan hijau juga di batasi sumber daya baru (minimalkan sumber daya baru) Desain bangunan harus meminimalkan penggunaan bahan baru untuk mengoptimalkan bahan yang ada, dan dapat digunakan kembali untuk membentuk tata letak arsitektur lainnya di akhir masa pakai bangunan. Serta secara keseluruhan Melalui integrasi kelima poin di atas dalam proses desain, kita dapat memahami desain bangunan.

Tujuan dari penelitian ini adalah menganalisis dan mengetahui prinsip- prinsip pendekatan arsitektur hijau yang dapat mendukung perubahan perilaku dimasa pandemi Covid-19 pada Alun-Alun Kota Batam (Dataran Engku Putri). Hasil dari penelitian ini diharapkan mendukung perubahan perilaku dimasa pandemi Covid-19 melalui penataan arsitektur di AlunAlun Kota Batam.

\section{BAHAN DAN METODE}

Metode penelitian yang digunakan dalam penelitian ini adalah kualitatif deskriptif. Selain itu, dalam penelitian ini diperlukan studi literatur untuk membandingkan teori dengan hasil penelitian di lapangan. Studi literatur merupakan sebuah metode penelitian yang mencari informasi dan membaca literatur dilakukan melalui buku, jurnal, berita online, dan laporan penelitian. Dalam penelitian ini, studi literatur dilakukan dengan mencari informasi dan membaca buku, jurnal, berita online, dan laporan penelitian mengenai arsitektur hijau yang mendukung adaptasi 
perilaku masyarakat di era pandemi Covid-19. Tahapan dalam penelitian ini terdiri dari pengumpulan data, sintesis, analisis data, menuliskan hasil dan pembahasan, serta menarik kesimpulan dan saran (Heriyanto, 2018).

\section{HASIL DAN PEMBAHASAN}

Prinsip-prinsip Pendekatan Arsitektur Hijau yang dapat Mendukung Perubahan Perilaku dimasa Pandemi Covid-19

Laporan Risiko Global 2019 menunjukkan bahwa dunia international belum siap akan pandemi global. Wabah ini semakin hari semakin tinggi, dengan 1.012 wabah penyakit tercatat antara 1980 dan 2013. Organisasi Kesehatan Dunia (WHO, 2020) memeriksa 7.000 tanda baru Potensi epidemi, dan untuk pertama kalinya pada Juni 2018, 6 dari 8 kategori epidemi dimasukkan dalam daftar "epidemi prioritas" WHO. Ada 5 alasan meningkatnya jumlah epidemi. Orang lebih mudah bepergian dan berpindah-pindah, sehingga meningkatkan pergerakan jarak jauh orang dalam waktu singkat, yang berarti jika terjadi wabah maka epidemi akan menyebar dengan cepat. Kedua, kepadatan penduduk tinggi dan tingkat kesadaran kesehatan rendah $55 \%$ penduduk lebih banya tinggaldi perkotaan. Ketiga, masalah deforestasi makin meningkat, yang menjadi penyebab merebaknya Ebola, Zika dan Nipah. Keempat, perubahan iklim telah mendorong penyebaran penyakit menular seperti virus Zika, malaria, dan demam berdarah. Kelima, komunitas yang mengungsi karena kemiskinan, konflik, dan keadaan darurat membuat semakin banyak orang rentan terhadap ancaman wabah penyakit. Selain itu, kemajuan penelitian juga menunjukkan bahwa keanekaragaman hayati yang tinggi dapat mengurangi penyebaran patogen dan mengurangi risiko berjangkitnya penyakit pada manusia (Webb Jr, 2013).

Pandemi Covid-19 ini membuktikan bahwa setiap RTH membutuhkan desain yang komprehensif. Ruang publik tak hanya bisa memenuhi kebutuhan sosial dan ekonimnya, tetapi juga berperan dalam memenuhi kesehatan fisik dan mentalnya. Prinsip dalam membangun serta mendesain ruang terbuka hijau harus multi fungsi, sehingga memperoleh manfaat. Salah satu metode yang memenuhi prinsip tersebut adalah metode bangunan hijau. Selain itu, harus ada cara yang tepat, mudah dijangkau oleh semua lapisan masyarakat, sehingga diperlukan metode dari semua ukuran. Konsep pembinaan dan pengelolaan lansekap perkotaan dalam masa pemulihan dari pandemi Covid-19 terbagi menjadi tiga skala yaitu makro (regional), meso (perkotaan) dan mikro (lingkungan / rumah).

Pakar lanskap dilatih untuk mengadopsi pendekatan holistik untuk perencanaan dan desain, dan mencapai tujuan komersial dan publik serta membangun lanskap yang fleksibel. Jurusan ini ideal untuk membentuk visi, keahlian teknis, kreativitas, dan pragmatisme yang dibutuhkan oleh generasi baru seniman hijau terintegrasi. Seniman hijau merupakan interaksi tiga sistem, yaitu jasa ekosistem, kesehatan ekosistem, dan kesehatan fisik dan mental manusia. Jika seseorang mengonsumsi makanan yang bergizi, berolahraga dengan benar dan tidak tercemar, maka kesehatan fisik sangat penting untuk melawan berbagai penyakit (Austin, 2014). Oleh karena itu, pada masa pandemi, prioritas tinggi diberikan untuk merancang konsep green building di lingkungan fisik yang dapat mendukung kesehatan dan meningkatkan kualitas hidup manusia.

Dalam penerapan prinsip-prinsip Pendekatan Arsitektur Hijau yang dapat Mendukung Perubahan Perilaku dimasa Pandemi Covid-19 antara lain terdiri dari terdiri dari hemat energi, kerjasama dengan iklim, hargai situs, memperhatikan pengguna bangunan, serta Penataan Arsitektur Hijau yang dapat Mendukung Perubahan Perilaku dimasa Pandemi Covid19.

\section{Hemat energi}

Dalam membangun arsitektur hijau yang dapat mendukung perubahan perilaku selama pandemi Covid-19, yakni mencapai konsumsi energi yang baik dengan meminimalkan konsumsi air conditioning (AC), elevator, dan eskalator. Selain itu, naungan dan taman vertikal digunakan pada bangunan hijau untuk mengatur intensitas cahaya yang masuk ke dalam ruangan dan panas berlebih. Berdasarkan penelitian Alun-alun Kota Batam belum menerapkan hal tersebut dalam penerapan konsep green building pada Alun-Alun Kota Batam. Namun akibat pandemi Covid-19, jam operasional beberapa gedung di sekitar Alun-Alun Batam (Daratan Engku Putri) berubah. Perubahan ini secara tidak langsung menyebabkan penghematan energi.

\section{Kerja sama dengan iklim (kondisi pemanfaatan dan energi alam)}

Bangunan hijau ini dirancang dengan menggunakan kondisi alam, iklim dan lingkungan sekitarnya. Arah bangunan mengikuti arah matahari. Selain itu, dengan mengoptimalkan udara alami, udara bersih dan sejuk menggunakan ventilasi silang dapat masuk ke dalam ruangan, serta memanfaatkan tanaman air sebagai pengatur iklim. Hal ini sebagaimana yang terdapat di Alun-Alun Kota Batam belum ditemukan pemanfaatan energi alam. Namun arah bangunan hijau yang ada di sekitar alun-alun dirancang berdasarkan kondisi alam, kondisi iklim Indonesia serta kondisi alam sekitar.

\section{Hargai situs (sesuai dengan kondisi situs bangunan) Bangunan hijau ini dirancang dengan mengacu pada interaksi antara bangunan dengan tapak, se- hingga bangunan tersebut mengikuti bentuk tapak. Dengan setidaknya tidak merusak lingkungan sekitar, keberadaan bangunan tersebut juga sangat baik dari}


segi struktur, bentuk dan pengoperasiannya. Berdasarkan penelitian yang dilakukan pada alun-alun kota Batam telah dilakukan penyesuaian situs bangunan.

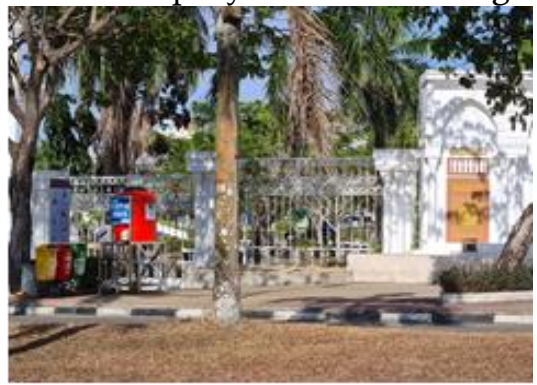

Gambar 1. Tempat cuci tangan dan tempat sampah (Dokumentasi Peneliti)

\section{Menghormati penggunaan (memperhatikan pengguna bangunan)}

Bangunan hijau yang dirancang untuk mendukung perubahan perilaku selama pandemi Covid-19 harus menarik perhatian pengguna karena telah menerapkan prinsip bangunan hijau dengan menggunakan pencahayaan alami dan ventilasi alami. Guna mendukung perubahan perilaku, rancangan alun-alun kota Batam terdapat beberapa tempat yang disediakan tempat cuci tangan serta handsanitizer dan tempat sampah. Selain itu, disediakan pula himbauan berupa banner tentang protokol kesehatan seperti pada gambar 2 .

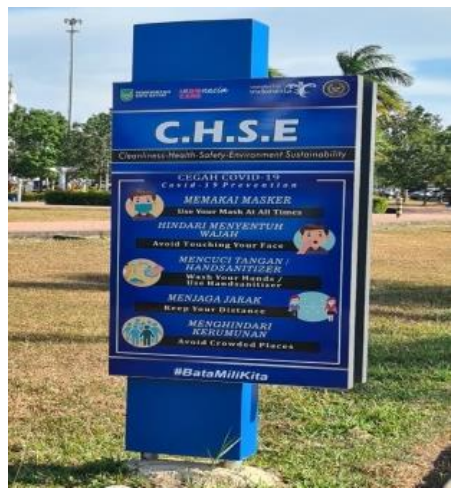

Gambar 2. Himbauan dalam menghindari Covid-19 (Dokumentasi Peneliti)

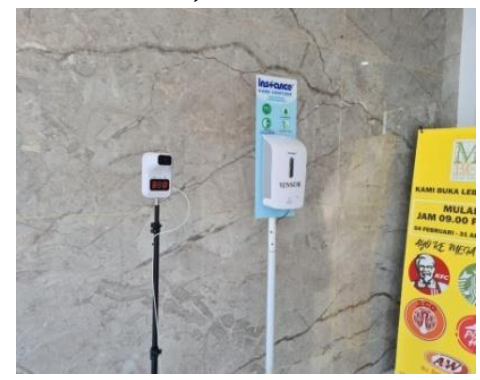

Gambar 3. Handsanitizer dan pengukur suhu tubuh (Dokumentasi Peneliti)

Batasi sumber daya baru (minimalkan sumber daya baru) Rancang bangunan hijau dengan mengoptimalkan material yang ada dan mengurangi penggunaan material baru. Selain itu, dalam perancangan ruang terbuka hijau, pemanfaatan grey water merupakan hal yang terpenting, karena memiliki reservoir air hujan pada daerah resapan, yang kemudian diolah kembali sehingga dapat digunakan untuk pembilasan toilet dan penyiraman tanaman. Dalam hal ini, Alun-Alun Batam telah menerapkan hal tersebut dengan adanya daerah resapan untuk air hujan.

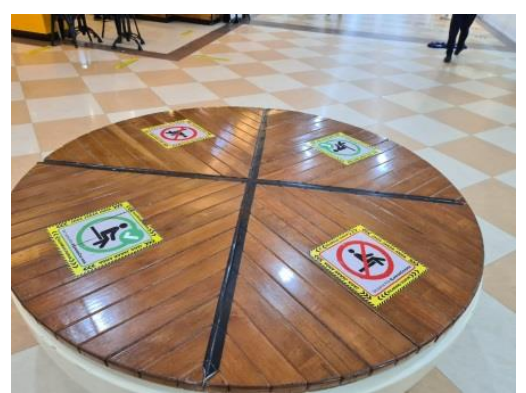

Gambar 4. Tempat duduk dan peringatan jaga jarak (Dokumentasi Peneliti)

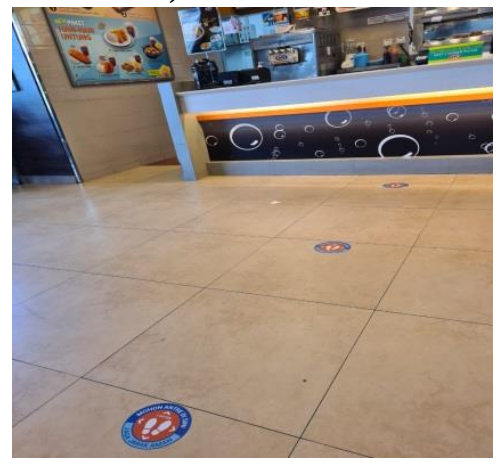

Gambar 5. Peringatan jaga jarak pada jalur antrean (Dokumentasi Peneliti)

Secara keseluruhan (Holistik) Bangunan yang digunakan untuk ruang terbuka hijau menerapkan prinsip green building dengan mendesain ruang terbuka hijau. Ruang terbuka hijau tersebut dapat memanfaatkan kondisi bangunan, merespon kondisi lokasi konstruksi dalam gedung, meminimalkan sumber daya, menghemat energi dan fokus pada pengguna. Hal tersebut nampak pada alun-alun kota Batam yang juga menerapkan konsep green building pada alunalunnya.

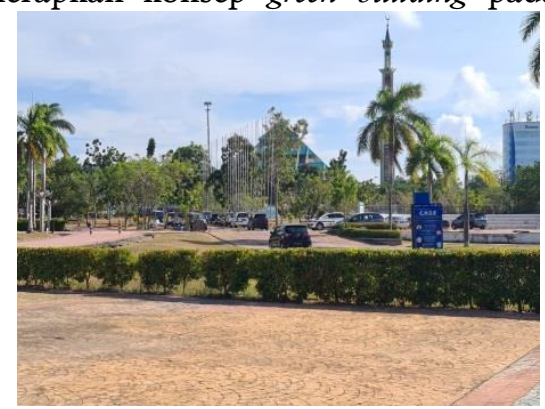

Gambar 6. Lahan terbuka hijau dan lahan parkir (Dokumentasi Peneliti) 
Penataan Arsitektur Hijau yang dapat Mendukung Perubahan Perilaku dimasa Pandemi Covid-19

Wabah Pandemi Covid 19 yang saat ini terjadi di seluruh negara termasuk Indonesia menimbulkan dampak yang sangat besar terhadap kondisi fisik dan psikologis masyarakat. Ribuan orang kehilangan nyawa, dan bahkan saat ini Indonesia memiliki jumlah kematian tertinggi kedua di Asia Tenggara. Tingginya angka kematian di Indonesia menunjukkan bahwa di bawah premis untuk meminimalkan penyebaran virus, rendahnya kualitas desain perkotaan tidak mengarah pada penciptaan tempat-tempat umum yang tahan epidemi. Salah satu rekomendasi pemerintah adalah tetap di rumah. Hal ini sebenarnya hanya bisa dilakukan oleh golongan sosial tertentu, sedangkan yang lain harus tinggal di rumah dan menggunakan tempat umum untuk menghidupkan kehidupannya. Area pejalan kaki yang sempit, fasilitas sanitasi yang kurang memadai, dan penduduk perkotaan yang setiap hari tercemar membuat virus Covid-19 lebih cepat menyebar (Feriawan, 2020). Karena fasilitas umum yang tidak memadai, rekomendasi pemerintah lainnya seperti menjaga jarak fisik, cuci tangan dan menjaga kekebalan menjadi sangat sulit.

Dalam arsitektur lansekap terdapat dua elemen utama yaitu Hardscape dan Softscape, dimana Hardscape adalah elemen keras, seperti patung, bangku taman, gerbang, biliar, dll dan Softscape adalah tanaman. Sebagai tempat dengan fungsi tertentu dapat terdiri dari jalan setapak, jembatan, gazebo, gerbang, tempat rekreasi buatan seperti waterpark, kolam pemancingan, art space, meeting place, lookout tower, dan elemen-elemen yang berhubungan dengan kegiatan seperti bangku taman, tong sampah, dll. Kegiatan ini tentunya dengan adanya kehidupan sosial yang baru, terutama social distance, tentunya berimplikasi pada desain. Misalnya pejalan kaki di kawasan wisata seperti pada gambar memiliki lebar $100 \mathrm{~cm}$ dan koridor di dalam ruangan, jika dalam kondisi penuh, kejadian berulang pasti akan bertabrakan, dan itu berdasarkan perbaikan tatanan baru.

\section{Penataan Arsitektur Hijau berdasarkan ruang}

Ruang yang dimaksud di sini dapat berupa area pejalan kaki, area, rest area, lapangan olah raga, dan lain-lain, tempat orang berkumpul. 1) Dimungkinkan untuk merancang kawasan baru untuk maju, terutama dengan membuat lebar jalan sesuai aturan jarak sosial, yaitu 1 meter. Jika lebar alas 1 orang adalah $60 \mathrm{~cm}, 2$ orang akan menjadi $120 \mathrm{~cm}+100 \mathrm{~m}$ (jarak sosial) dan lebarnya adalah $220 \mathrm{~cm}$. Untuk menambah ruang yang digunakan per orang, misalnya jika diatur sesuai standar sebelum hidup baru, setiap orang $4 \mathrm{~m}^{2}$, setelah jarak sosial dimungkinkan untuk menambah ukuran menjadi $2 \mathrm{x}$, yaitu $8 \mathrm{~m}^{2}$, jadi bahwa total permintaan ruang meningkat.

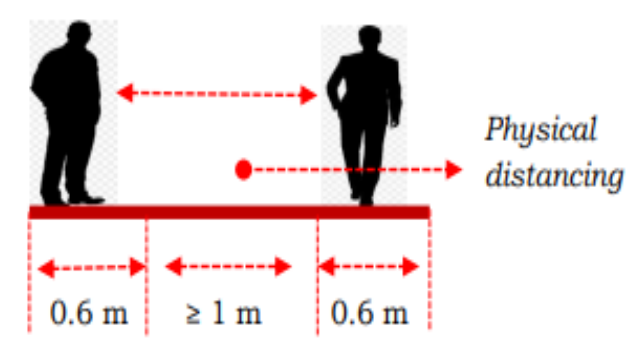

Gambar 7. Penataan Ruang dengan Konsep Jaga Jarak

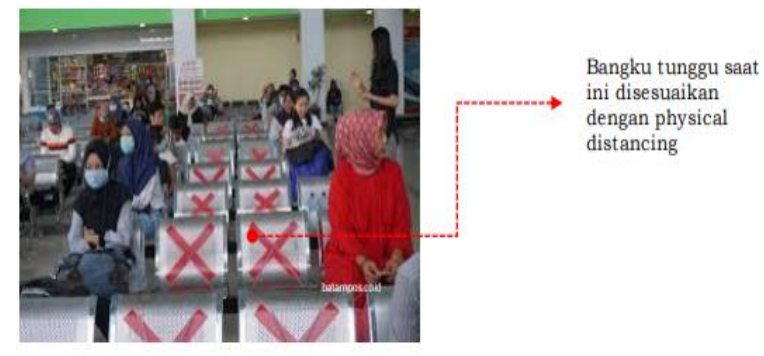

Gambar 8. Penataan Bangku Ruang Tunggu yang disesuaikan Physical Distancing

Desain bangku taman, ruang tunggu yang disesuaikan dengan kondisi pandemi dengan konsep social distancing sebenarnya bisa lebih dikembangkan karena memiliki keunggulan: (1) Lebih murah, (2) Ditempatkan untuk bank dan taman, memiliki keunggulan maksiat menjadi berkurang. anak muda mengurangi kedekatan dengan taman / area tenang di taman. Sedangkan kekurangannya adalah membutuhkan ruang yang lebih besar untuk daya tampung orang, sehingga pada umumnya membutuhkan ruang agregat yang lebih besar, jika tidak memungkinkan untuk menambah ruang maka mengakibatkan pengurangan daya tampung orang/pengguna, misalnya: jika ruang kursi cukup untuk 100 orang dengan 25 baris kursi dengan empat kursi maka jarak fisik dikurangi menjadi hanya 50 orang, dan jika kita mendesain yang baru, luas ruangan harus dua kali lebih besar.

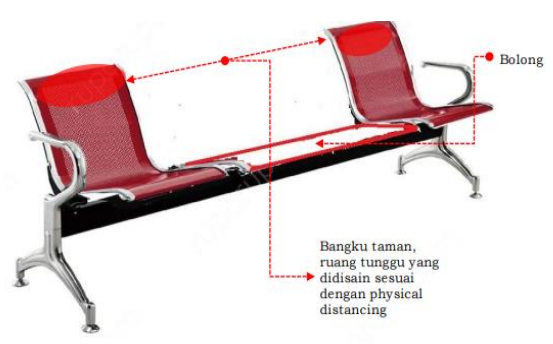

Gambar 9. Penataan Bangku Taman yang disesuaikan Physical Distancing

(https://encrypted-tbn0.gstatic.com/images?q=tbn:ANd9GcQPE2kCF_Y6xNce4b6rNCQcgIix3S1065tcg\&usqp=CAU/) 


\section{Penataan Arsitektur Hijau berdasarkan Material}

Berdasarkan pengamatan para dokter virus dari sisi material, kemungkinan virus hidup lebih lama pada material tertentu, dan tidak terkena sinar matahari, oleh karena itu pemilihan material sangat penting dalam rangka kehidupan energi yang baru, seperti menggunakan bahan elemen logam. Lebih lama lagi, sangat berbahaya untuk daerah dengan tingkat hunian tinggi, atau selama musim liburan, sehingga ketika merencanakan dan merancang harus mempertimbangkan masalah konsumsi bahan dengan pertimbangan bahwa virus tidak dapat lagi diatasi terakhir. Oleh karena itu perlu memperhatikan desain elemen mana yang sering disentuh oleh pengguna, berdasarkan persediaan, jenis bahan dan cara pengolahan ditentukan agar virus tidak berlama-lama.

Persoalan yang harus diperhatikan di tingkat makro merupakan kaitan ruang terbuka hijau. Sambungan ruang terbuka hijau yang berkualitas tinggi dapat membawa banyak manfaat, seperti melindungi keanekaragaman hayati, meningkatkan kualitas udara dan air, menyediakan ruang bagi masyarakat untuk berolahraga, dan meningkatkan estetika lingkungan. Kalung Zamrud adalah infrastruktur hijau pertama dalam sejarah arsitektur lanskap yang dirancang oleh Frederick Law Olmsted pada tahun 1878. Ini menghubungkan lima kebun raya dengan total panjang 11, 3 kilometer dan mencakup area seluas 445 hektar. Infrastruktur hijau ini adalah warisan yang luar biasa, dan masih ada. Rute transportasi (mobil, kereta api, sepeda), sungai dan batas kota merupakan tipe lanskap yang cocok untuk koridor, sedangkan taman kota dan hutan adalah petak. Dengan cara ini, semakin banyak bidang tanah yang dihubungkan dengan koridor hijau akan meningkatkan konektivitas lanskap.

Masalah skala menengah adalah kualitas ruang terbuka hijau kita. Ruang terbuka hijau perkotaan yang ada masih didominasi oleh orientasi estetika, dengan mengabaikan kualitas ekologis. Kualitas ekologi ruang terbuka hijau perkotaan dapat ditingkatkan dengan menerapkan komponen bangunan hijau seperti kehutanan kota, restorasi ekologi dan pengelolaan air hujan. Jalan perkotaan dan trotoar juga bukan prioritas utama dalam Perencanaan tata ruang kota membuat banyak dari mereka tidak ramah pejalan kaki. Hal ini mempengaruhi preferensi orang yang suka melakukan aktivitas di dalam ruangan dan menggunakan mobil pribadi, sehingga mengakibatkan berkurangnya permintaan untuk berolahraga, sehingga menurunkan tingkat kesehatan masyarakat. Ruang terbuka hijau tidak dapat menyediakan fasilitas sanitasi berkualitas tinggi, seperti tempat cuci tangan dan toilet, yang merupakan masalah penting dalam menangani penyebaran penyakit. Selain itu, taman kota dapat digunakan sebagai sarana edukasi tentang wabah penyakit, yaitu merancang taman peringatan dini terkait Covid-19. Taman memorial ini merekam situasi di Indonesia selama periode Covid-19, sehingga dapat memberikan informasi dan meningkatkan kesadaran akan wabah penyakit di masyarakat dan generasi yang akan datang.

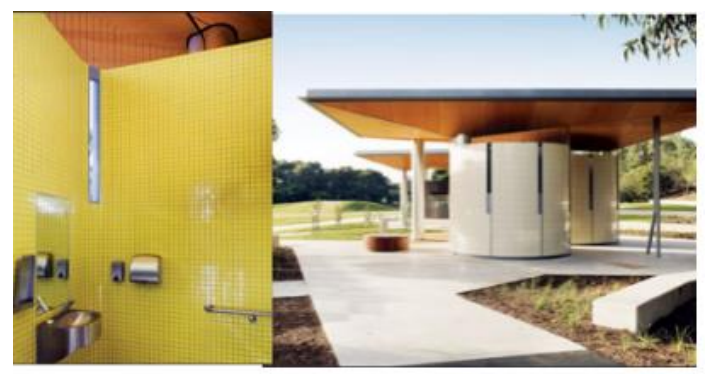

Gambar 10. Penataan Fasilitas Toilet Publik yang Memenuhi Standar

(https://media3.architecturemedia.net/site_me$\mathrm{dia} / \mathrm{me}$

dia/cache/84/85/8485ed8e0f5a1110074463c14f1937 5c.jpg)

Selain itu, dalam kaitannya dengan konsep cuci tangan memiliki implikasi desain, yaitu dengan menempatkan wadah air dan sabun, yang kebanyakan contoh di foto, area cuci tangan akan menjadi area berbahaya di mana bahan keran. apakah kran air cucian atau kran kancing sabun ditangani oleh banyak orang, sehingga perencanaan dan perancangan perlu memikirkan otomatisasi atau cara agar kaleng dan kancing sabun tidak terjamah oleh siapapun, tempat terbaik dari area cuci tangan sebelumnya pengguna / tamu memasuki ruangan sekitar untuk mengurangi penyebaran.

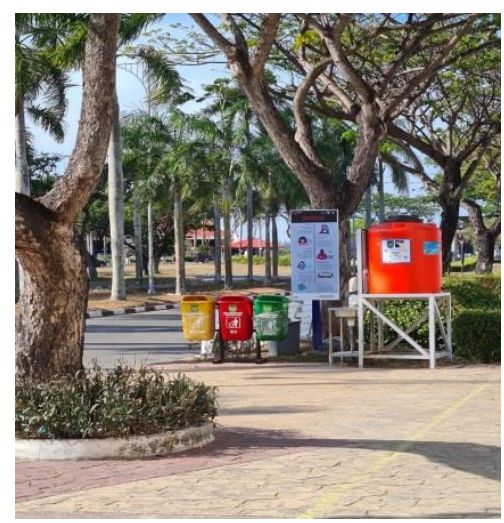

Gambar 11. Penataan Konsep Cuci Tangan di AlunAlun Kota Batam.

(Dokumentasi pribadi)

\section{KESIMPULAN}

Kondisi pandemi Covid-19 memaksa sebagian besar orang untuk tetap aktif di rumah dalam jangka waktu yang lama. Situasi ini menginspirasi para arsitek dan perencana lingkungan untuk mendukung adaptasi perubahan perilaku selama pandemi Covid-19 melalui penggunaan konsep bangunan hijau untuk menyesuaikan dengan tata letak dan ruang terbuka bangunan untuk menciptakan karya. 
Berdasarkan hasil penelitian yang dilakukan ditemukan bahwa Alun-Alun Kota Batam belum menerapkan hal tersebut dalam penerapan penghematan energi pada Alun-Alun Kota Batam. Namun akibat pandemi Covid-19, jam operasional beberapa gedung di sekitar Alun-Alun Batam (Daratan Engku Putri) berubah. Perubahan ini secara tidak langsung menyebabkan penghematan energi.

Dalam hal kondisi pemanfaatan dan energi alam, di Alun-Alun Kota Batam belum ditemukan pemanfaatan energi alam. Namun arah bangunan hijau yang ada di sekitar alun-alun dirancang berdasarkan kondisi alam, kondisi iklim Indonesia serta kondisi alam sekitar.

Dalam hal penyesuaian situs, alun-alun kota Batam telah dilakukan penyesuaian situs bangunan. Dalam hal memperhatikan pengguna bangunan, rancangan alun-alun kota Batam terdapat beberapa tempat yang disediakan tempat cuci tangan serta handsanitizer dan tempat sampah. Hal ini dilakukan guna mendukung perubahan perilaku kebiasaan baru. Selain itu, terdapat banner yang berisikan imbauan protokol kesehatan. Disisi lain, dalam penampungan air hujan, Alun-Alun Batam telah menerapkan daerah resapan untuk air hujan.

\section{UCAPAN TERIMAKASIH}

Penelitian ini dilaksanakan dengan baik berkat bantuan dari berbagai pihak, untuk itu peneliti mengucapkan terima kasih kepada Ibu Suzana Ratih Sari dan Bapak Agung Budi Sardjono yang telah membimbing penulis dalam penulisan jurnal ini. Ucapan terima kasih juga penulis sampaikan untuk keluarga tercinta yang telah memberi dukungan moril sehingga penulisan jurnal ini dapat diselesaikan.

\section{DAFTAR PUSTAKA}

Anisa. (2014). Penerapan green building pada rumah adat Kudus. Majalah Sains Dan Teknologi, Vol.6 No. 2.

Austin, G. (2014). Green Infrastructure for Landscape Planning. In Green Infrastructure for Landscape Planning. https://doi.org/10.4324/9781315856780

C. Otegbulu, A. (2011). Economics of Green Design and Environmental Sustainability. Journal of Sustainable Development. https://doi.org/10.5539/jsd.v4n2p240

Cole, L. B. (2019). Green building literacy: a framework for advancing green building education. International Journal of STEM Education. https://doi.org/10.1186/s40594-019-0171-6

Ding, Z., Fan, Z., Tam, V. W. Y., Bian, Y., Li, S., Illankoon, I. M. C. S., \& Moon, S. (2018). Green building evaluation system implementation. Building and Environment.

https://doi.org/10.1016/j.buildenv.2018.02.012
Dunia, D. J. O. K. (2020). Pidato pembukaan oleh Direktur Jenderal Organisasi Kesehatan Dunia pada konferensi pers tentang COVID-19. https://www.who.int/dg/presentation/details/ who-director-general-s -\%0ApembukaanKeterangan dalam pengarahan media tentang Covid-19-11

Feriawan, H. (2020). Bangunan hijau mendukung adaptasi perubahan perilaku. https://www.beritasatu.com/nasional/710879/ar sentuk-hijau-menduku ng-adaptation-changebehaviour

Heldavidson. (2020a). Kasus Covid-19 pertama terjadi pada November, catatan pemerintah Tiongkok menunjukkan 2020.

https://www.theguardian.com/world/2020/mar/ 13/first-covid-19-case-happened+-+di-

+November-laporan+tampilan-

catatan+pemerintah+Cina

Heldavidson. (2020b). Kasus Covid-19 pertama terjadi pada November, catatan pemerintah Tiongkok menunjukkan 2020.

Heriyanto, H. (2018). Thematic Analysis sebagai Metode Menganalisa Data untuk Penelitian Kualitatif. Anuva. https://doi.org/10.14710/anuva.2.3.317-324

Hidayat, F., Setiyono, B., Putranti, I. R., Dwimawanti, I. H., \& Kaukab, M. E. (2020). Green Building Asset Management Toward The End Of Usefulness: A Case Of The Relocation Of Jakarta To New Jakarta. PalArch's Journal of Archaeology of Egypt/Egyptology, 17(6), 1064610660.

Jimmy Priatman. (2002). "ENERGY-EFFICIENT ARCHITECTURE" PARADIGMA DAN MANIFESTASI ARSITEKTUR HIJAU. DIMENSI (Jurnal Teknik Arsitektur).

Nicola, M., Alsafi, Z., Sohrabi, C., Kerwan, A., A1Jabir, A., Iosifidis, C., Agha, M., \& Agha, R. (2020). The socio-economic implications of the coronavirus pandemic (COVID-19): A review. In International Journal of Surgery. https://doi.org/10.1016/j.ijsu.2020.04.018

NIH. (2020). New coronavirus stable for hours on surfaces . National Institutes of Health .

Oebaidillah, S. (2020). Pandemi Covid-19 Menginspirasi Arsitektur Hijau.

https://mediaindonesia.com/humaniora/369864 /pandemi-covid-19-menginspirasi-arsitektur-hijau

Olubunmi, O. A., Xia, P. B., \& Skitmore, M. (2016). Green building incentives: A review. In Renewable and Sustainable Energy Reviews. https://doi.org/10.1016/j.rser.2016.01.028

Pradono, B. (2008). Desain hijau dari perspektif arsitek muda. In Bisnis yang bagus dengan desain ramah lingkungan. Universitas Brawijaya.

Rachael D'amore. (2020). Coronavirus: Where did it come from and how did we get here? 
Melinda Leony, Suzanna Ratih Sari| DLI 9 (1) (2022) 1-8 8

Shen, Y., \& Faure, M. (2020). Green building in Vasishta, P. A., Anjali, A. K., Brundha, M. P., \& China. International Environmental Agreements: Politics, Law and Economics. https://doi.org/10.1007/s10784-020-09495-3

Vale, B. (2017). Building materials. In Materials for a Healthy, Ecological and Sustainable Built Environment: Principles for Evaluation. https://doi.org/10.1016/B978-0-08-1007075.00003-4 Sivaswamy, V. (2020). An overview on pandemic COVID-19. International Journal of Research in Pharmaceutical Sciences. https://doi.org/10.26452/ijrps.v11iSPL1.3068

Zhao, X., Zuo, J., Wu, G., \& Huang, C. (2019). A bibliometric review of green building research 2000-2016. In Architectural Science Review. https://doi.org/10.1080/00038628.2018.1485548. 